\title{
Activity of Rosaceae Juss. family species in some high-altitudinal plant communities of the Western Sayan and Kuznetsky Alatau (Khakassia)
}

\author{
Elena Sazanakova ${ }^{1 *}$ and Natalia Tupitsyna ${ }^{2}$ \\ ${ }^{1}$ N. F. Katanov Khakas State University, Lenina str., 90, Abakan, 655000, Russia \\ ${ }^{2}$ V. P. Astafyev Krasnoyarsk State Pedagogical University, Ada Lebedeva str., 89, Krasnoyarsk, \\ 660017, Russia
}

\begin{abstract}
In the studied high-altitudinal phytocenoses of the Western Sayan and Kuznetsky Alatau, 22 species and 7 genera of Rosaceae Juss. family are identified, they were found in communities of 3 associations: Flavocetrario cucullatae-Dryadetum oxyodontae (lichen-dryad tundra), Cladonio stellaris-Betuletum rotundifoliae (bushy-lichen tundra) and Aquilegio glandulosae-Anthoxanthetum odorati (alpine low grass meadow). The activity of species of Rosaceae family is the highest in Flavocetrario cucullatae-Dryadetum oxyodontae association due to Dryas oxyodonta (55.90, 3 species), then in descending order Cladonio stellaris-Betuletum rotundifoliae (48.12, 19 species) and Aquilegio glandulosae-Anthoxanthetum odorati (40.80, 11 species) go.
\end{abstract}

\section{Introduction}

Family Rosaceae Juss. includes more than 3.000 species and about 115 genera [1] and is among the leading families in terms of the family spectrum of Khakassia flora [2]. Its representatives are often dominant and subdominant of phytocenoses. The role of the family in the vegetation cover is determined both by the number of species and their activity [3]. According to our data, Rosaceae family in the flora of Khakassia has 102 species and 26 genera [4], which is $3.4 \%$ (3.000 species) of the world flora of the family and 29.3\% (348 species) of Rosaceae family of Asian Russia [5]. In the flora of the Yenisey Sayans [6], which includes the entire southern part of Khakassia, as well as in the flora of the northwestern part of the Altai-Sayan province [7], which includes the northwestern Khakassia, Rosaceae family is in sixth position, and in some of its areas it reaches higher positions.

Khakassia is a part of the Altai-Sayan mountain region, it includes the western part of the northern macroslope of the Western Sayan, the eastern slope of Kuznetsky Alatauthe Kuznetsk Highlands, the western part of Minusinsk Basin. Khakassia is located at the

*Corresponding author: sazelevik@mail.ru 
junction of the Circumboreal and Iran-Turan Regions of the Holarctic Kingdom [8], near the borders of mountain Altai-West-Sayan and Sayan-Baikal floristic provinces [9].

\section{Materials and methods}

Field works were carried out in 2016-2017 by standard technique [10]. 33 complete geobotanical releves were made in the Western Sayan: the ridges of Sailyg-Khem-Taiga, Kokhosh, Monysh, the valley of the Big On river and in Kuznetsky Alatau: Pustaskhyl, Chalbakh-Taskhyl, Kharykh-Taskhyl mountains and the surroundings of Lake Rybnoye. Releves were attributed to 3 syntaxa described before [11-16]. According to eco-floristic approach, the studied high-altitude communities are classified in the following way:

Class Carici rupestris-Kobresietea bellardii Ohba 1974

Order Kobresietalia myosuroides Mirkin et al. (1983) 1986

All. Dryadion oxyodontae Zhitlukhina et Oniščenko ex Chytrý, Pešout et Anenkhonov 1993

Ass. Flavocetrario cucullatae-Dryadetum oxyodontae Zibzeev, Nedovesova 2014

Class Loiseleurio-Vaccinietea Eggler ex Schubert 1960

Order Betuletalia rotundifoliae Mirkin et al. ex Chytrý, Pešout et Anenkhonov 1993

All. Empetro-Betulion rotundifoliae Zhitlukhina et Oniščenko 1987

Ass. Cladonio stellaris-Betuletum rotundifoliae Telyatnikov 2015

Class Mulgedio-Aconitetea Hadač et Klika in Klika et Hadač 1944

Order Schulzio crinitae-Aquilegietalia glandulosae Ermakov, Shaulo et Maltseva 2000

All. Schulzio crinitae-Aquilegion glandulosae Ermakov, Shaulo et Maltseva 2000

Ass. Aquilegio glandulosae-Anthoxanthetum odorati Krasnoborov ex Ermakov et. al. 2000

List of species of every association is considered as coenoflora. The activity of the species of Rosaceae family was calculated in each of three coenoflora using the formula made by L.I. Malyshev and Yu.N. Petrochenko [17] and modified by M.Yu. Telyatnikov [18].

\section{Results and discussion}

Dryas oxyodonta Juz. is found in all three types of communities, activity optimum of the species is ass. Flavocetrario cucullatae-Dryadetum oxyodontae (51.66). In the Western Sayan (Sailig-Khem-Taiga ridges), the coenoses of this association are confined to the altitudes from $2205 \mathrm{~m}$ to $2303 \mathrm{~m}$ above sea level (alpine belt). They inhabit the tops of mountains in windy areas with a low level of snow cover. In Kuznetsky Alatau (Pustaskhyl mountain), communities are located from $1273 \mathrm{~m}$ to $1524 \mathrm{~m}$ above sea level, and are present in the upper part of the mountain tundra belt. They inhabit the slopes of the northern exposure. The association is dominated by dwarf shrubs (Dryas oxyodonta, Empetrum nigrum L., Vaccinium vitis-idaea L.) and lichens (Flavocetraria cucullata (Bellardi) Kärnefelt et A. Thell, F. nivalis (L.) Kärnefelt et A. Thell, Thamnolia vermicularis (Sw.) Schaer.). Mosses are negligible (Aulacomnium turgidum (Wahlenb.) Schwägr., Pleurozium schreberi (Brid.) Mitt., Rhytidium rugosum (Hedw.) Kindb.). Dryas oxyodonta is often the dominant and edificator, the plant cover of the species is 7-60\%. The average species number is 29 species per $100 \mathrm{sqm}$.

In the Western Sayan, communities of ass. Cladonio stellaris-Betuletum rotundifoliae are were studied on the ridges of Sailyg-Khem-Taiga, Kokhosh, Monysh and in the valley of the Big On river. The altitude ranges from $1704 \mathrm{~m}$ to $2269 \mathrm{~m}$ above sea level (subalpine belt). This association occupies the drained, non-steep mountain slopes (10-20 $)$ of various 
orientations, and descends in the lower part of the sub-goltsy belt to the valley of the Big On mountain river. In Kuznetsky Alatau (the saddle between Chalbakh-Taskhyl and Kharykh-Taskhyl mountains, near Lake Rybnoy), the association is located in the upper part of the mountain-tundra belt. The altitude ranges from $1.385 \mathrm{~m}$ to $1.524 \mathrm{~m}$ above sea level. The association occupies the summits of mountains in the areas of temporary streams after snow melting, depressions, zones of fractures, it descends lower down to the subalpine belt. The main dominants are shrubs (Betula rotundifolia Spach, Salix glauca L., S. myrtilloides L.), lichens (Cladonia rangiferina (L.) FH Wigg., C. stellaris (Opiz) Pouzar et Vezda, Cetraria islandica (L.) Ach., Flavocetraria cucullata, F. nivalis, Thamnolia vermicularis) and shrubs (Empetrum nigrum, Vaccinium vitis-idaea). In this association, Dryas oxyodonta is less active (22.04). Species of Alchemilla genus (12 species) are widely represented in the Western Sayan in the headwaters of the Big On river; Alchemilla krylovii Juz. (4.10) and Alchemilla sibirica Zamelis (2.88) have a higher activity. Species A. anisopoda Juz., A. aperta Juz., A. bungei Juz., A cryptocaula Juz., A dasyclada Juz., A. diglossa Juz., A. lipschitzii Juz., A. omalophylla Juz., A. orbicans Juz., A. subcrenata Buser are found occasionally. The average species number of ass. Cladonio stellarisBetuletum rotundifoliae is 38 species per 100 sqm.

Ass. Aquilegio glandulosae-Anthoxanthetum odorati unites alpine low grass meadows. It is noted in the Western Sayan on the ridges Sailyg-Khem-Taiga, Kokhosh and Monysh. The altitude ranges from $1859 \mathrm{~m}$ to $2116 \mathrm{~m}$ above sea level. This association is located in the sub-goltsy belt near the snowfields, in the areas of seepage humidification, in small depressions, on steep $15-30^{\circ}$ mountain slopes of northeastern orientation. In Kuznetsky Alatau it is noted at the foothills of Pustoskhyl mountain, near Lake Rybnoye. The altitude ranges from $1463 \mathrm{~m}$ to $1520 \mathrm{~m}$ above sea level. In the alpine low grass meadows, Dryas oxyodonta is the least active (0.63), rare and scant species. In this association, species of Alchemilla genus are quite active: Alchemilla dasyclada (4.47), A. leiophylla (4.47), A. krylovii (3.46), A. sauri (3.46). The average species number of ass. A. g. $\boldsymbol{A}$. $\boldsymbol{o}$. is 33 species per $100 \mathrm{sqm}$.

Sibbaldia procumbens $\mathrm{L}$. is noted in the same association. In the Western Sayan, this species is common, but scant. The species is common and highly active (18.33) in alpine low grass meadows of Kuznetsky Alatau.

Dasiphora fruticosa (Fisch. Ex Lehm.) Juz. is widely represented as part of shrub layer in ass. Aquilegio glandulosae-Anthoxanthetum odorati (3.46) and ass. Cladonio stellarisBetuletum rotundifoliae (3.53) due to frequent occurrence and small plant cover.

22 species and 7 genera of Rosaceae family are identified in the high-altitudinal communities of the Western Sayan and Kuznetsky Alatau. The species activity is shown in table 1 .

Table 1. The species activity of Rosaceae family of high-altitude communities in the Western Sayan and Kuznetsky Alatau

\begin{tabular}{|c|c|c|c|}
\hline \multirow{2}{*}{ Species of the Rosaceae family } & \multicolumn{3}{|c|}{ Associations } \\
\hline & F.c. - D. o. & C. s. - B. $r$. & A. g. - A. o. \\
\hline Alchemilla anisopoda & - & 1.33 & 0.63 \\
\hline Alchemilla aperta & 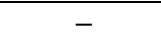 & 0.77 & - \\
\hline Alchemilla bungei & - & 0.24 & - \\
\hline Alchemilla cryptocaula & - & 0.24 & - \\
\hline Alchemilla dasyclada & - & 0.24 & 4.47 \\
\hline Alchemilla diglossa & - & 0.24 & - \\
\hline Alchemilla krylovii & - & 4.10 & 3.46 \\
\hline Alchemilla leiophylla & - & - & 4.47 \\
\hline Alchemilla lipschitzii & - & 0.77 & - \\
\hline Alchemilla omalophylla & - & 0.24 & 0.63 \\
\hline
\end{tabular}




\begin{tabular}{|l|c|c|c|} 
Alchemilla orbicans & - & 0.77 & - \\
\hline Alchemilla sauri & - & - & $\mathbf{3 . 4 6}$ \\
\hline Alchemilla sibirica & - & 2.88 & 0.63 \\
\hline Alchemilla subcrenata & - & 0.24 & 0.63 \\
\hline Cotoneaster uniflorus & - & 0.24 & - \\
\hline Dasiphora fruticosa & - & $\mathbf{3 . 5 3}$ & 3.46 \\
\hline Dryas oxyodonta & $\mathbf{5 1 . 6 6}$ & $\mathbf{2 2 . 0 4}$ & 0.63 \\
\hline Potentilla evestita & - & 2.18 & - \\
\hline Potentilla gelida & 0.77 & $\mathbf{5 . 1 5}$ & - \\
\hline Potentilla nivea & $\mathbf{3 . 4 7}$ & - & - \\
\hline Sibbaldia procumbens & - & 2.43 & $\mathbf{1 8 . 3 3}$ \\
\hline Spiraea alpina & - & 0.49 & - \\
\hline Total: & $55.90 / 3$ species & $48.12 / 19$ species & $40.80 / 11$ species \\
\hline
\end{tabular}

\section{Conclusion}

The activity of species of the Rosaceae family is highest in lichen-dryad tundra ass. Flavocetrario cucullatae-Dryadetum oxyodontae - 55.90 (3 species), in bushy-lichen tundra ass. Cladonio stellaris-Betuletum rotundifoliae - 48.12 (19 species), in alpine low grass meadows ass. Aquilegio glandulosae-Anthoxanthetum odorati- 40.80 (11 species).

This paper was supported by a grant No 18-44-24006 "Natural and urbanized floras of Trans-Yenisei Siberia" given by the Russian Foundation for Basic Research and the Krasnoyarsk Regional Supporting Fund of Scientific and Technical Activities.

\section{References}

1. R.V. Kamelin, Rosaceae (Barnaul, Altaiskye Stranitsy, 2006)

2. The vegetation cover of the Khakassia (Novosibirsk, Science, 1976)

3. B.A. Yurtsev, Flora Suntar-Hayat: Problems of the history of high-altitude landscapes of North-Eastern Siberia (Leningrad, Science, 1968)

4. E.V. Sazanakova, N.N. Tupitsyna, Vestnik KrasGAU, 4 (115) (2016)

5. Synopsis of flora of Asiatic Russia: Vascular plants (Novosibirsk, SD RAS, 2012)

6. N.V. Stepanov, Vascular plants of the Yenisei Sayan (Krasnoyarsk, Sib. Fed. University, 2016)

7. A.L. Ebel, Synopsis flora north-western part of the Altai-Sayan province (Kemerovo, KREOO «Irbis», 2012)

8. A.L. Takhtajan, The floristic regions of the World (L., Science, 1978)

9. R.V. Kamelin, Problems of botany of South Siberia and Mongolia (Barnaul, AzBuka press, 2002)

10. A.A. Yunnatov, Field geobotany. 3 (M.-L., Science, 1964)

11. E. G. Zibzeev, Sib. Bot. journal, 2, 2 (2007)

12. N.B. Ermakov, The current status of the basic scientific concepts of vegetation (Ufa, Gilem 2012)

13. E.G. Zibzeev, E.A. Basargin, Herald of Novosibirsk State University. Series Biology, clinical medicine, 10, 2 (2012)

14. E.G. Zibzeev, T.A. Nedovesova, Turczaninowia, 17, 3 (2014)

15. M.Yu. Telyatnikov, Flora of Asian Russia, 3 (19) (2015) 
16. E.A. Basargin, E.G. Zibzeev, Flora of Asian Russia, 1 (29) (2018)

17. L.I. Malyshev, Bot. Journal, 58, 11 (1973)

18. M.Yu. Telyatnikov, Siberian Ecological Journal, 6 (2010) 